\title{
Corrosion of limestone tablets in sulfidic ground-water: measurements and speleogenetic implications
}

\author{
Sandro Galdenzi ${ }^{1}$
}

\begin{abstract}
:
Galdenzi S. 2012. Corrosion of limestone tablets in sulfidic ground-water: measurements and speleogenetic implications. International Journal of Speleology, 41(2), 149-159. Tampa, FL (USA). ISSN 0392-6672. http://dx.doi.org/10.5038/1827-806X.41.2.3

The measurement of the weight loss in limestone tablets placed in the Grotta del Fiume (Frasassi, Italy) provided data on the rate of limestone dissolution due to the sulfidic water and on the influence of local environmental conditions. A linear average corrosion rate of $24 \mathrm{~mm} \mathrm{ka}^{-1}$ was measured in stagnant water, while the values were higher $\left(68-119 \mathrm{~mm} \mathrm{ka}^{-1}\right)$ where the hydrologic conditions facilitate water movement and gas exchanges. In these zones the increase in water aggressivity is due to mixing with descending, $\mathrm{O}_{2}$-rich, seepage water and is also favored by easier gas exchange between ground-water and the cave atmosphere. Very intense corrosion was due to weakly turbulent flow, which caused evident changes in the tablets shape in few months. A comparison between the measured corrosion rates and the cave features showed that the values measured in the pools with stagnant water are too low to account for the largest solutional cave development, while the average values measured in the zones with moving water are compatible with the dimension of the cave rooms in the main cave levels, that must have developed when the base level was stable and hydrologic conditions favored the increase of water aggressivity.
\end{abstract}

Keywords: karst corrosion; sulfidic water; limestone tablets; Frasassi caves

Received 10 November 2011; Revised 29 January 2012; Accepted 7 February 2012

\section{INTRODUCTION}

Many caves in the world were formed by sulfuric acid solution, one of the most efficient and rapid mechanisms of cave development. In these caves, the oxidation of $\mathrm{H}_{2} \mathrm{~S}$ dissolved in the water is the most important source of water aggressiveness. The $\mathrm{H}_{2} \mathrm{SO}_{4}$ produced in the process interacts with the limestone, contributing to its dissolution. In a limestone cave, the most evident byproduct is the deposition of replacement gypsum on the cave walls exposed to $\mathrm{H}_{2} \mathrm{~S}$ exhalations.

The corrosion due to $\mathrm{H}_{2} \mathrm{~S}$ released by the groundwater was thought capable of creating entire caves (Principi, 1931; Egemeier, 1981). The dissolution of limestone however also occurs underwater, and the development of caves in deep zones of a sulfidic aquifer have been hypothesized in Guadalupe Mountains caves (Davis, 1980; Hill, 1987), while the co-existence of important solutional processes above and below the water-table was documented in the Frasassi caves (Galdenzi, 1990).

Caves produced by sulfuric acid reaction are generally hypogenic and are known in different hydrogeology and morphologic conditions (Palmer 1991; Klimchouk \& Ford, 2009). Some active caves are known in the world, although few of them have been

${ }^{1}$ Viale Verdi, 10 Jesi, Italy (galdenzi.sandro@tiscali.it) studied to get information about the mechanism of the cave development or the role of microbes: Cueva de Villa Luz (Hose et al., 2000), Movile (Sarbu \& Kane, 1995), Frasassi (Sarbu et al., 2000; Macalady et al., 2006, 2007), Lower Kane Cave, Engel et al., 2004).

Limestone corrosion rates due to sulfidic water were measured in the Grotta del Fiume at Frasassi, where limestone tablets were exposed for five years in the cave (Galdenzi et al., 1997). The corrosion rates were high, both in the water and in the atmosphere.

The tablets exposed to acidic exhalations in the cave atmosphere were covered by a layer of replacement gypsum, and the limestone surface below the gypsum layer was severely corroded, with deep pockets. The weight loss in these tablets reached high values (linear corrosion rate up to $85 \mathrm{~mm} \mathrm{ka}^{-1}$, with gypsum being removed before each measurement), and the average rate increased from 42 to $69 \mathrm{~mm} \mathrm{ka}^{-1}$ after 2.5 and 5 years of exposure. The site conditions strongly influenced the results and significant differences occurred in tablets located only a few $\mathrm{cm}$ apart, depending on the acidic flow path.

The corrosion rate of tablets placed underwater was about $58 \mathrm{~mm} \mathrm{ka}^{-1}$, and the rate did not vary depending on the length of exposure and site conditions. The limestone had a slightly rough surface with calcite veins protruding in relief (Fig. 1). Similar measurements made in another noncirculating body of water in Frassasi (Mariani et al., 2007) resulted in low corrosion values. 


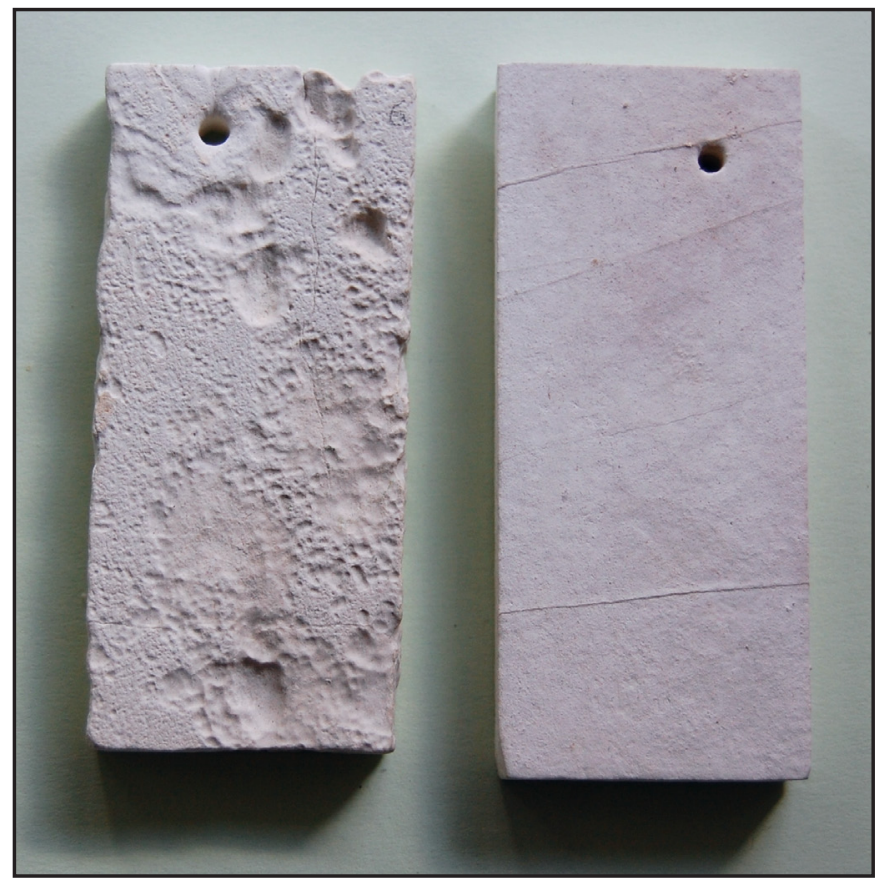

Fig. 1. Limestone tablets after five years of exposure in the cave (after Galdenzi et al., 1997). A tablet placed in the ground-water (right) and one corroded in the cave atmosphere, after the removal of the replacement gypsum (left).

In this paper, the results of a new cycle of measurements will be discussed. Some limestone tablets were newly placed in the cave with the purpose to quantify the corrosion due to the direct action of ground-water in different setting and through different seasons. In this case corrosion due to $\mathrm{H}_{2} \mathrm{~S}$ in the cave air was not measured.

\section{THE USE OF LIMESTONE TABLETS}

The use of limestone tablets to quantify the rate of erosion in the surface karst processes was introduced by Trudgill (1975) and Gams (1985). This method was also used to measure active corrosion processes due to sulfidic water in the cave environment (Galdenzi et al., 1997).

The same procedure used by Galdenzi et al. (1997) to prepare the limestone tablets was also used here to better compare the old and new data. The tablets were prepared with limestone blocks taken from local quarries. A pure micritic limestone (Calcare Maiolica Fm., Early Cretaceous) was used due to its homogeneity facilitating the preparation and weighing of tablets, and also because the cave develops at least in part in this formation.

The limestone was cut into tablets about $8 \times 4 \times$ $0.8 \mathrm{~cm}$, which were polished, measured in detail to get their total surface area, and weighed after being dried at $110^{\circ} \mathrm{C}$. Their initial mass varied between 60 and $70 \mathrm{~g}$. The tablets were placed in the cave using a nylon string and, at the end of the exposure period, they were washed, dried and weighed again. The ratio between weight loss and area of each tablet was then referred to a standard period of exposure to get comparable data. For this reason, the weight loss is reported as $\mathrm{mg} \mathrm{cm} \mathrm{cm}^{-2} \mathrm{a}^{-1}$ represented as an estimated linear corrosion rate $\left(\mathrm{mm} \mathrm{ka}^{-1}\right)$.

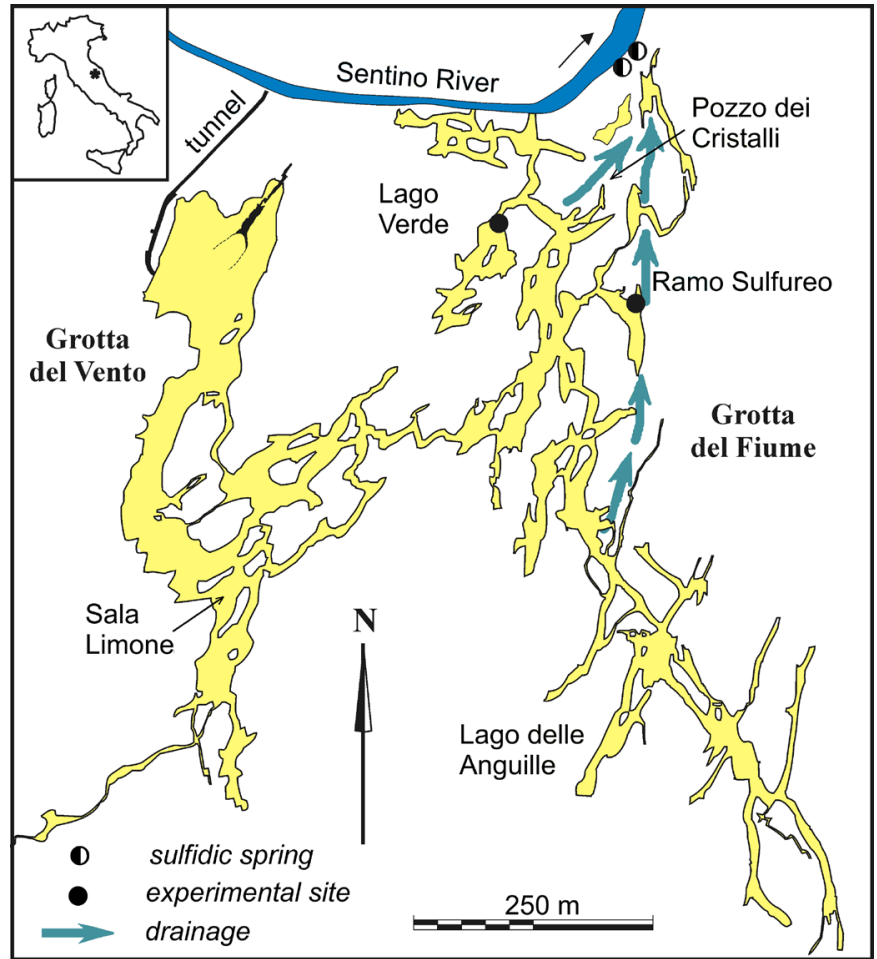

Fig. 2. Plan view of the caves

The limestone tablets were placed in different cave pools to verify the local corrosion rate and compare it with the data already acquired in Ramo Sulfureo (Galdenzi et al., 1997). The experiment started in November 2006, with a planned duration of two years, and two different sites were chosen: Lago Verde, in the Grotta del Fiume, the most important cave in the Frasassi Gorge and the Grotta Sulfurea, close to the sulfidic spring (Fig. 2).

In June 2007 a new set of tablets was placed in the Grotta del Fiume to verify a possible influence of seasonal cycles on the corrosion rate. These tablets were placed in Ramo Sulfureo, exactly in the same place as the 1997 experiments. One tablet remained continuously in the water for two years, while some tablets were placed and removed from the same location according to season. Some tablets were used in the wet period, and the others in the dry period. Each "seasonal" tablet therefore was placed, removed, weighted and newly placed following the hydrologic cycle. An additional "seasonal" station was also created in the Lago Verde, near the previously placed tablets.

During the measurement period, technical difficulties resulted in changes to the planned procedure. In particular the station in the Grotta Sulfurea was soon discarded. Seasonal changes in flow moved the soft sediment in the bottom of the pool disrupting the conditions of tablet exposure. For this reason, Ramo Sulfureo and Lago Verde remained the only monitored places.

Throughout the whole period, data loggers placed in the cave got almost continuous data on water level and conductivity. These instruments stayed in the cave for an independent study of the ground-water flow patterns, which data are useful also in the discussion of experimental results on the corrosion rate. 


\section{THE CAVE HYDROLOGY}

The ground-water chemistry is well known, and a recent study provides detailed information (Galdenzi et al., 2008). The sulfidic water in the main aquifer is cold $\left(\sim 13^{\circ} \mathrm{C}\right)$, and has a higher salinity (up to $2 \mathrm{~g}$ $\mathrm{L}^{-1}$ ) than the normal bicarbonate water infiltrating from the karst surface. It is enriched in sodium and chloride, and contains sulfate and hydrogen sulfide. Mixing phenomena between descending bicarbonate and rising mineralized water determine the composition of the ground-water in the shallow phreatic zone. The calculated freshwater dilution during the study year (2001) varied between 30 and 60\% depending on the season. Significant differences in water chemistry were also found among different sampling sites. Some pools of the cave, as Lago Verde, are fed more directly from a deep zone of the aquifer, with a lower contribution of freshwater. In many cave lakes a layer of bicarbonate water formed above the sulfidic water due to the very slow ground-water flow.

The concentration of most cations and anions varied seasonally (Galdenzi et al., 2008). The sulfide concentration showed the widest fluctuations on a percentage basis, varying between 0.1 and $0.5 \mathrm{mmol}$ $\mathrm{L}^{-1}$. On the contrary bicarbonate concentration maintained more constant values $\left(4.0-4.7 \mathrm{mmol} \mathrm{L}^{-1}\right)$ during the year. In the Lago Verde, that is fed from deep zones of the aquifer, the dilution due to freshwater was relatively low (20\% maximum) and was related to the direct recharge of freshwater from the surface in the rainy periods.

Recent researches revealed that the disappearance of $\mathrm{H}_{2} \mathrm{~S}$ in the cave streams is mainly due to the release into the cave atmosphere, and that bacteria significantly increase the oxidation rate in the ground-water compared to abiotic processes (Jones et al., 2011).
The hydrologic year can be divided into two periods, roughly corresponding to a "wet season", in winter and spring, and a "dry season", in summer and autumn. These periods are poorly related to rain distribution, that evidence two maxima, the main one in autumn, and a secondary one in the spring. Only winter and spring precipitations directly influence the ground-water, because evapotranspiration in the summer and soil storage in the autumn reduce the amount of recharge. At the end of autumn, after strong rains, fast infiltration water reaches the ground-water, modifying the water chemistry and increasing the water level (Fig. 3).

The course of the annual hydrologic cycles determined the length of exposure for the "seasonal" tablets, even if the fast change of the hydraulic conditions at the end of autumn prevented the "seasonal" tablets from being placed exactly at the beginning of the "wet season". The data on water conductivity and level make it possible to compare tablets exposure and hydrologic cycles (Fig. 3) and also to know the general evolution of ground-water characteristics during the period. During the first part of the experiment (2006 and 2007) the total amount of rain was low, and it reduced the ground-water dilution, also causing a general, weak lowering of the water-table. Only after the intense rain in March 2008 the hydrologic conditions in the cave gradually returned to normal.

In the cave, the water level underwent simultaneous changes, within a similar range, in the different localities. Some peaks (up to over $1 \mathrm{~m}$ ) were due to short flood events, however the level usually varied only 40-60 cm. Water conductivity showed similar seasonal changes, with summer values that reach over $2000 \mathrm{\mu Scm}^{-1}$ (at $20^{\circ} \mathrm{C}$ ) at the end of summer, descending to $1000 \mu \mathrm{Scm}^{-1}$ or less as a consequence of freshwater dilution.

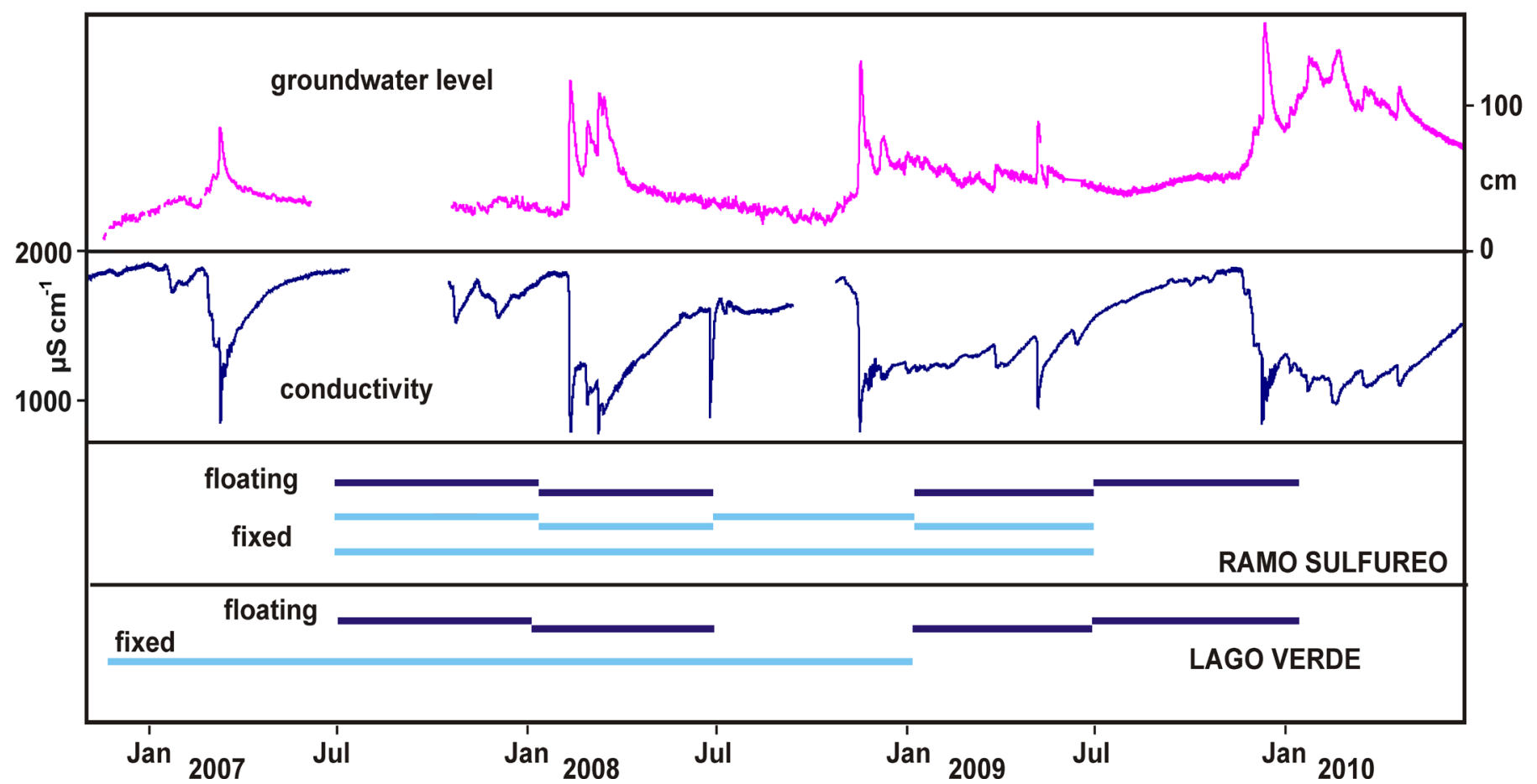

Fig. 3. Conductivity and levels of the sulfidic ground-water, related to the periods of tablets exposure during the experiment. 


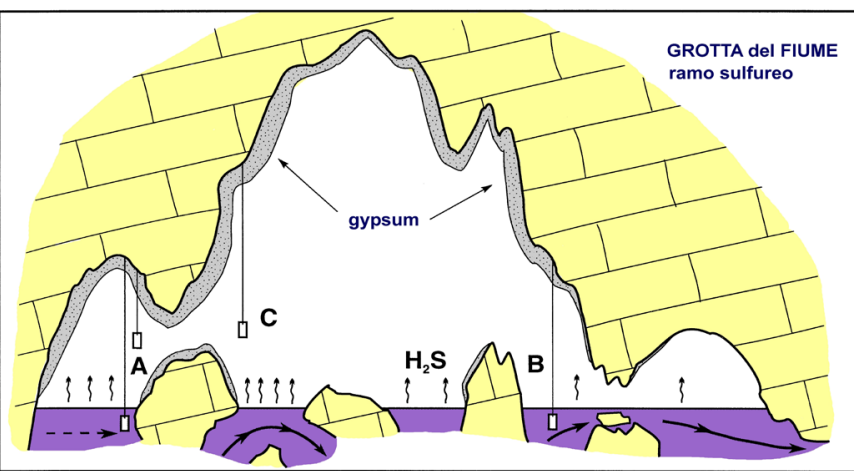

Fig. 4. Sketch of the experimental site in Ramo Sulfureo, with the stations used by Galdenzi et al. (1997). The station B was chosen for the present experiment.

\section{Ramo Sulfureo}

\section{THE EXPERIMENTAL SITES}

The Ramo Sulfureo is in the eastern part of Grotta del Fiume, a zone where sulfidic water actively flows in partly flooded passages (Fig. 2). In this zone, many sulfidic pools are directly in contact with the cave atmosphere, and $\mathrm{H}_{2} \mathrm{~S}$ released from the water produces limestone replacement and gypsum deposition on the cave walls. This site was already chosen for the 1997 measures of limestone corrosion (Fig. 4), when the tablets were placed in four different stations, both in the air and in the water.

For this study, all the tablets were located at only a single station, a sulfidic pool $\sim 1.5 \mathrm{~m}$ deep which had

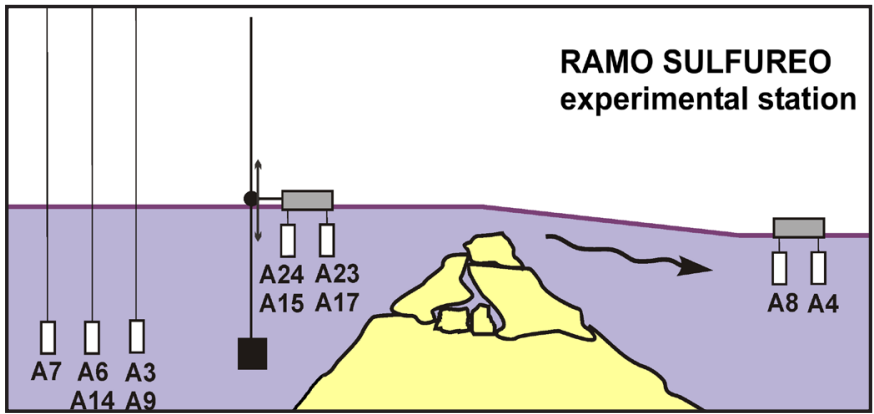

Fig. 6. Sketch of the experimental site in the Ramo Sulfureo, with the location of each tablet in the ground-water.

already been used in 1997. The water has a surface flow velocity $\sim 0.08 \mathrm{~m} \mathrm{~s}^{-1}$ at the end of the wet period. The pool ends downstream at a breakdown barrier that divides this pool from a small lake (Fig. 5). Here the water flow is weakly turbulent and the water velocity was measured up to $0.3 \mathrm{~m} \mathrm{~s}^{-1}$.

The tablets were placed in different settings, fixed and floating (Fig. 6). Three tablets were maintained in the same position tying them directly to the rock. Two of them were changed seasonally, the other one remained in the groundwater for the whole period (two years) (Fig. 3). A floating station was created tying the tablets to an empty bottle, allowing them to float a few centimeters below the water surface. These tablets were seasonally replaced. In the first semester, the bottle was placed in the lake downstream of the turbulent flow

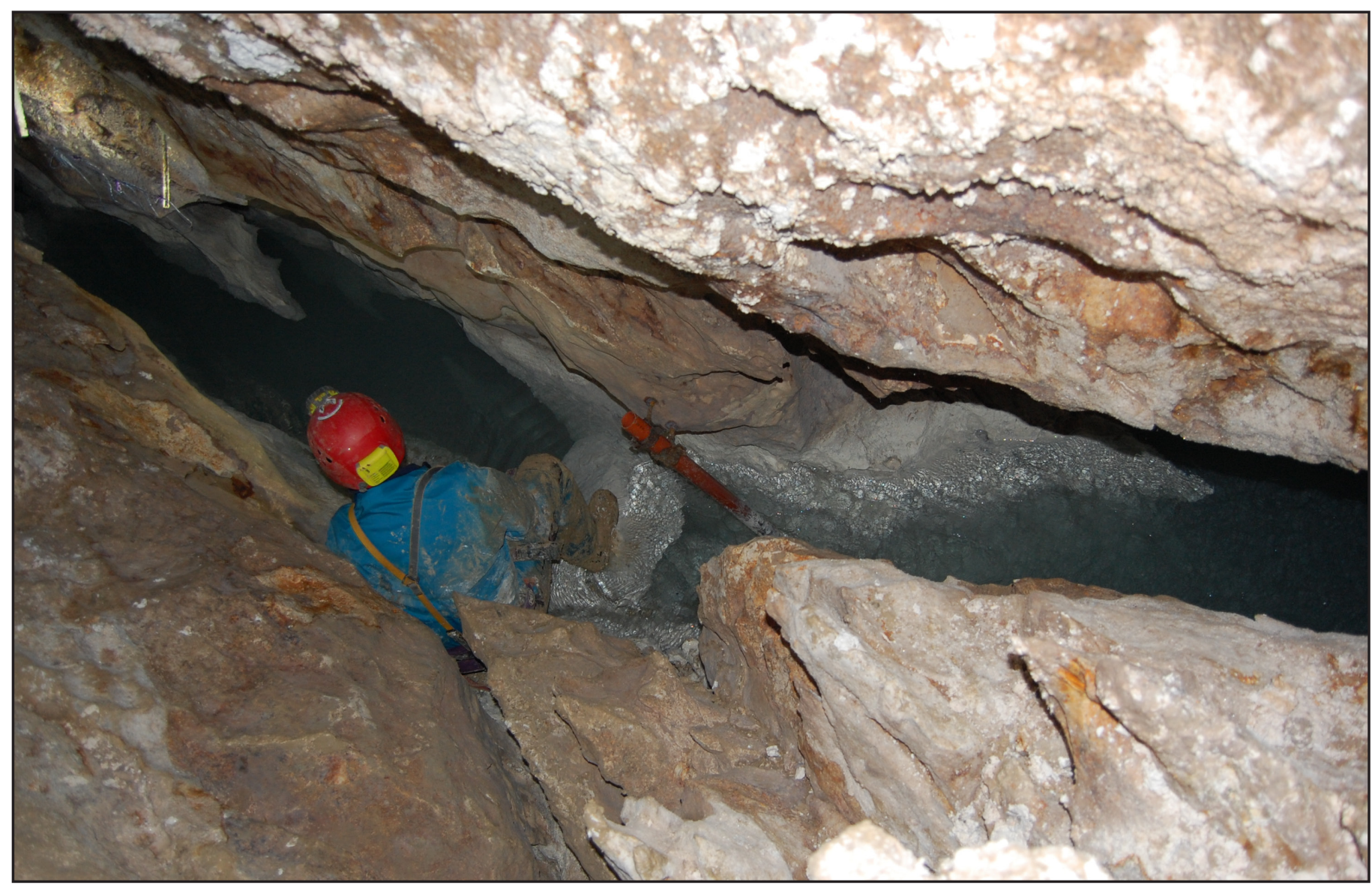

Fig. 5. Grotta del Fiume, Ramo Sulfureo: the experimental site. The speleologist stays on the breakdown barrier that causes turbulence downstream, at right. 


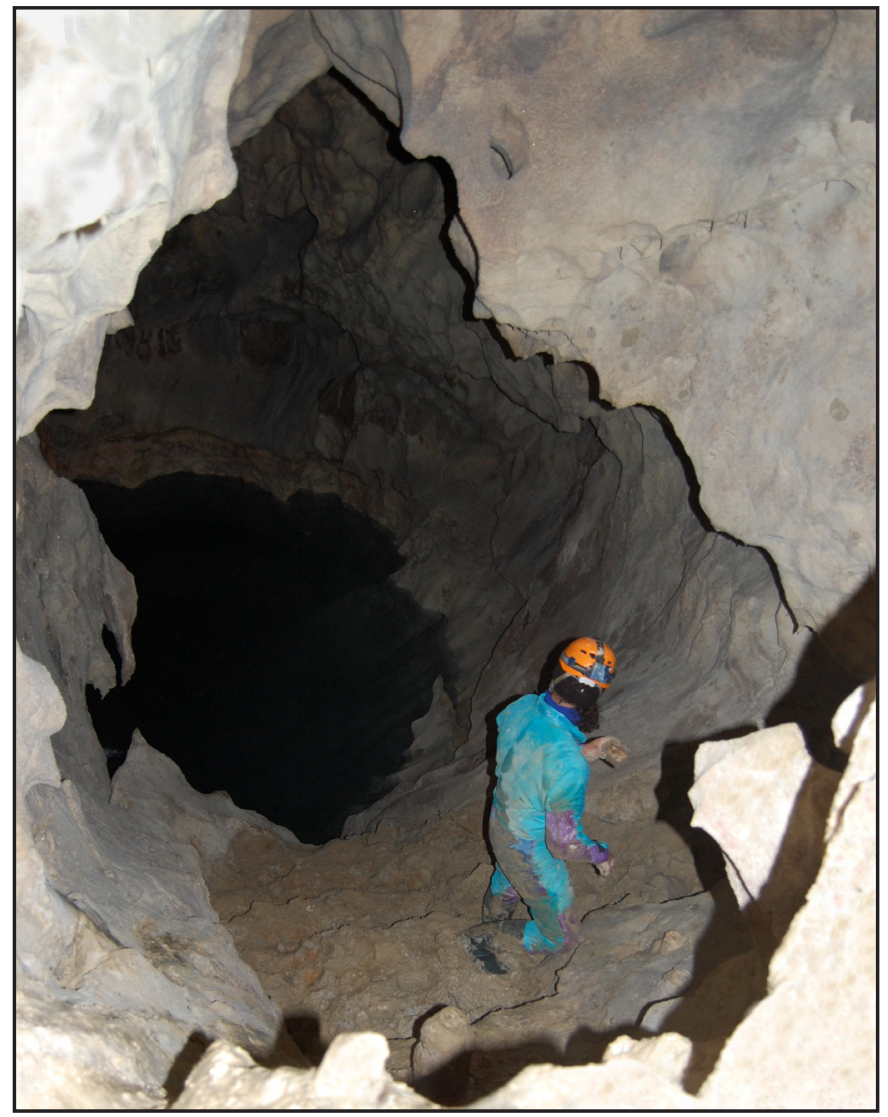

Fig. 7. Grotta del Fiume, Lago Verde: the experimental site.

zone (Fig. 6). In the following period, during the wet season, the bottle with the tablets was stranded by a rise in the water level of up to $1 \mathrm{~m}$ due to flooding. (Fig. 3). In the third time period the floating station was placed in the laminar flow zone upstream of the breakdown divide. At the end of this monitoring period, however, the bottle and tablets disappeared for unknown reasons and were found nowhere.

The floating bottle method was therefore repeated, using a different fastener, that permitted only vertical movements (Fig. 6). These tablets were left in the cave six months after all other tablets were removed (Fig. 3).

\section{Lago Verde}

The Lago Verde consists of two close pools of stagnant water, fed from the bottom. The ground-water has a higher salinity compared with most of the cave pools, but a weak surface dilution is often produced by seepage water. The tablets were placed in the most isolated pool, at the bottom of a small shaft (Fig. 7). Difficult accessibility prevented occasional damage in a cave area highly frequented by cavers and visitors. Two tablets were placed at different depths ( 20 and $170 \mathrm{~cm}$ below the lowest water level) for two years.

Even if it was not a part of the original project, a floating station was used to append two tablets near the water surface. The tablets were seasonally changed and weighed, as in Ramo Sulfureo. At the end of the second semester, one tablet was lost. The procedure was repeated for two further time periods (Fig. 3).

\section{RESULTS}

\section{Field observations}

Macroscopic differences among the tablets located in different places were readily apparent. The tablets in the Ramo Sulfureo were soon covered by a microbial mat that grew below the water level (Fig. 8). This organic layer is formed by chemotrophic bacteria, mainly sulfide-oxidants (Macalady et al., 2006) and represents the food source for invertebrates inhabiting the cave (Sarbu et al., 2000). These bacteria are also suspected to play an important role in the cave development, considering that $\mathrm{H}_{2} \mathrm{~S}$ oxidation produces sulfuric acid, increasing the water aggressivity (Galdenzi et al., 1999; Sarbu et al., 2000).

The organic layer was not macroscopically evident in the tablets placed in the turbulent downstream pool in Ramo Sulfureo. After only six months, these tablets were severely corroded, showing signs of turbulent flow on the tablet surface (Fig. 9). In the Lago Verde, where flow was completely stagnant, the limestone tablets acquired a dark surface coloration, due to a small amount of unoxidized organic matter.

\section{Weight loss}

Galdenzi et al. (1997) found significant differences in the corrosion rate only for tablets located in the cave atmosphere, depending on the flowpath of escaping $\mathrm{H}_{2} \mathrm{~S}$, while below the water level the rate at two different stations was the same $\left(\sim 58 \mathrm{~mm} \mathrm{ka}^{-1}\right)$, without variations related to the length of tablet exposure or to the velocity of water flow.

This new experiment revealed that the site conditions influence the corrosion not only in the cave atmosphere, but also in the ground-water, while

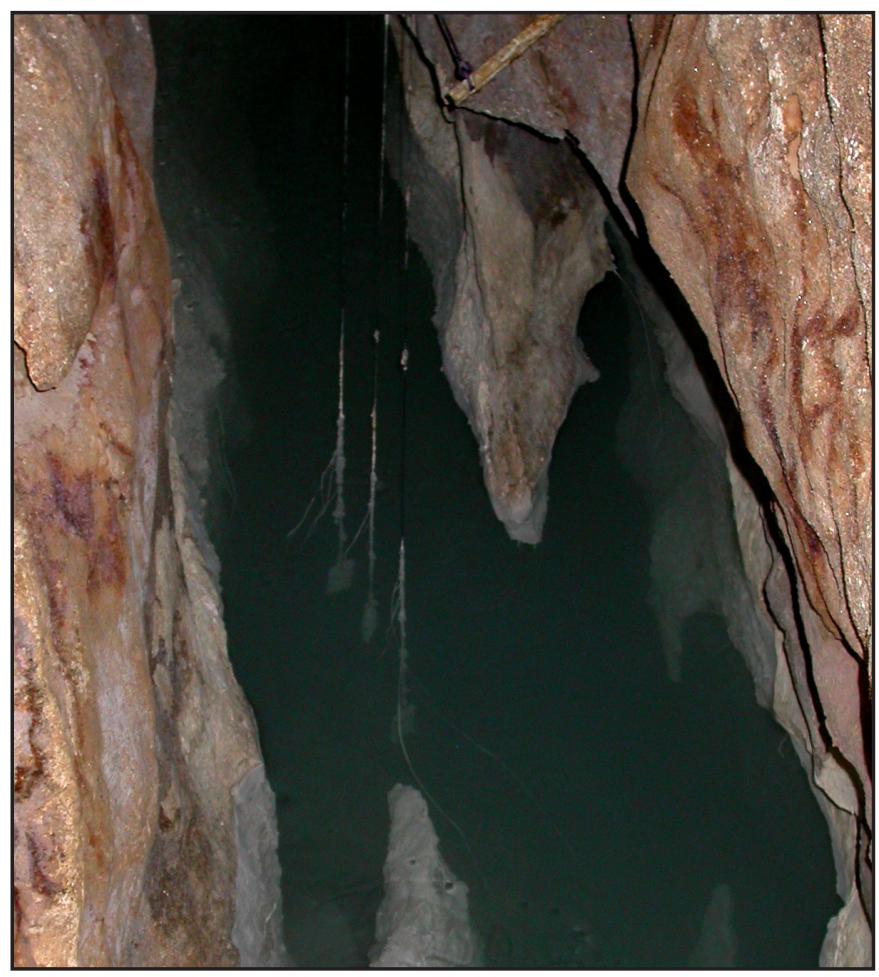

Fig. 8. The tablets and the strings covered by thick biofilm in the sulfidic ground-water. 


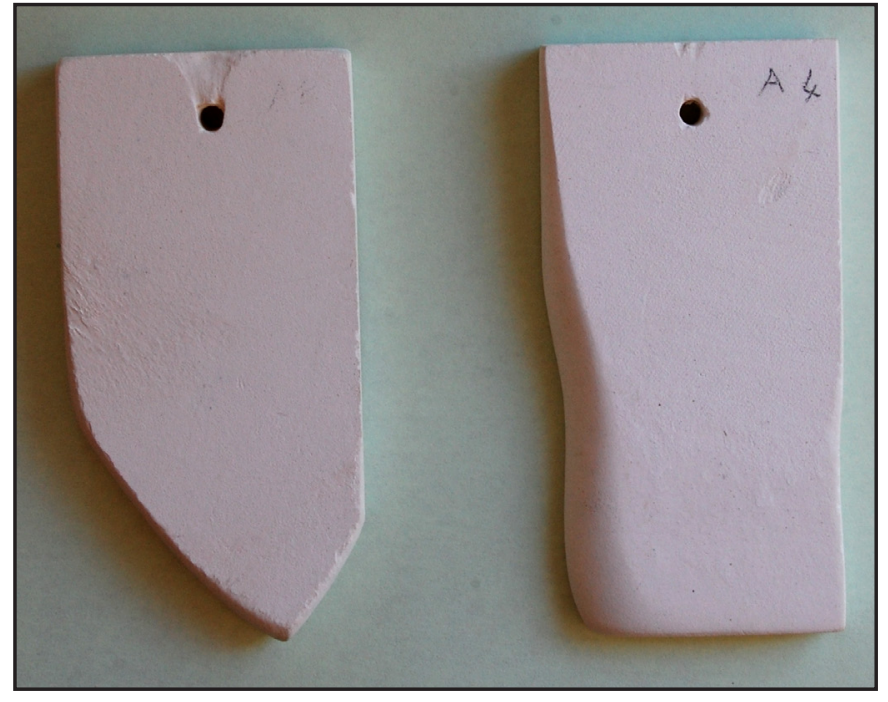

Fig. 9. The tablets exposed to turbulent flow after six months.

seasonal changes were not important. The values of weight loss, converted to corrosion rate, are listed in Tab. 1. The highest values (up to $960 \mathrm{~mm} \mathrm{ka}^{-1}$ ) was found in Ramo Sulfureo, in slowly running water that modified significantly the original shape of the tablets (Fig. 9). Excluding these two tablets, the calculated rates in Ramo Sulfureo are close to those already found in similar conditions by Galdenzi et al. (1997). The lowest corrosion rates were found in Lago Verde (average value: $24 \mathrm{~mm} \mathrm{ka}^{-1}$ ).

Compared to those results, very low values of corrosion are reported by Mariani et al. (2007) from the Lago delle Anguille, a cave lake with stratified stagnant water located in the inner zones of the same Grotta del Fiume (Fig. 2). The Authors report only the percentage of weigth loss, which was $\sim 0.08 \% \mathrm{a}^{-1}$ in the layer of sulfidic water, at a depth between 4.5 and $6.5 \mathrm{~m}$. This value can roughly be converted to a linear erosion rate of $\sim 1.5 \mathrm{~mm} \mathrm{ka}^{-1}$. These results, however, cannot be easily compared with the others reported in the cave by Galdenzi el al. (1997) and in the present experiment. Mariani et al., in fact, used tablets with a different size, made of pure crystalline Carrara marble, and the sulfidic ground-water produces a differential dissolution of micrite and calcite, as already shown (Galdenzi et al., 1997).

\section{Environmental factors \\ Nature of water flow}

The flow conditions had a great influence on the corrosion rate. All the values from Ramo Sulfureo were in moving water and are higher than in Lago Verde, a stagnant pool. Significant differences were also found at the different locations in Ramo Sulfureo, depending on water flow.

The highest values, almost $1000 \mathrm{~mm} \mathrm{ka}^{-1}$, were found for the floating tablets at the entrance to the lake. This strong increase in the corrosion rate was caused by the relatively fast water flow, evidenced by the hydrodynamic shape acquired by the tablets (Fig. 9) and is probably favored by the turbulence of the water at the lake entrance, facilitating gas exchanges with the atmosphere and, consequently, $\mathrm{H}_{2} \mathrm{~S}$ oxidation.
In the nonturbulent water body the rate varied within a narrow range (75-119 $\mathrm{mm} \mathrm{ka}^{-1}$ ) and was $27 \%$ higher for the tablet floating at the surface compared to the tablet placed at depth (Tab. 1). This difference is probably due more to the water velocity than to depth. In fact, the tablets located upstream, directly exposed to the flow (A8, A15, A24), were more intensely corroded than the others (A4, A17, A23).

\section{Hydrologic cycle}

The hydrologic cycle was not an important influence in the Ramo Sulfureo. The corrosion rate was $\sim 10 \%$ higher in the dry season for the fixed tablets, but this difference was not apparent in the floating station, where the corrosion rate did not change between the wet or dry seasons. A detailed interpretation of these data is difficult, because the change of the water-table level influenced the flow conditions in a different way for the fixed and floating tablets.

In the Lago Verde, where water flow is absent, the corrosion rate was variable and decreased significantly in the dry season. These changes can be related to the importance that seepage water had in the sulfidic water dilution depending on the amount of precipitation for the different seasons and years. In particular, the lowest value (tablet A5) corresponds to the dry season of 1997, after two years of drought, that caused less dilution at the surface of the lake. Low rates were also calculated for the tablets placed in 2009 during wet and dry periods, when the conductivity at the Lago Verde surface maintained high average values (2430 and $\left.2630 \mu \mathrm{Scm}^{-1}\right)$.

\section{Depth}

Depth of tablets did not have an evident influence on the corrosion rate. In the Ramo Sulfureo, where movement of the water prevents any stratification, the high values of the floating station seem due mainly to the different flow conditions.

The interpretation of the data in the stagnant water of Lago Verde is more complex. Here the permanent tablet was slightly more corroded, at $\sim 2 \mathrm{~m}$ depth (tablet B20) than near the surface (B22). On the contrary, the average corrosion rate for "seasonal" tablets at the lake surface is greater than both the fixed tablets. These contradictory results are probably due to the different amount of surface dilution during the exposure period of each fixed and floating tablet, in a lake where the amount of freshwater recharge directly influenced the dilution of the sulfidic water near the surface.

\section{Bacterial activity}

In the Ramo Sulfureo, a significant difference was found in the control tablet, that remained permanently in the water for two years. The corrosion rate for this tablet $\left(68 \mathrm{~mm} \mathrm{ka}^{-1}\right)$ is lower than those found for the seasonal tablets, both in the wet and dry seasons (79 and $88 \mathrm{~mm} \mathrm{ka}^{-1}$ ). The seasonal and control tablets stayed in the same place and these differences cannot be related to depth, water velocity or other factors. The lower corrosion rate of the control tablet might be related to the growth of a microbial mat. In the seasonal tablets this organic layer was always removed 
after six months, therefore the limestone surface was more directly exposed to water for long periods before the organic layer formed again.

Bacteria biofilms in this environment mainly consist of sulfide oxidizers (Macalady et al., 2006) and they surely contribute to increase the water aggressiveness, but they probably create a physical barrier that protects the limestone surface from dissolution.

\section{DISCUSSION}

The calculated corrosion rates are high in Ramo Sulfureo that is representative of the eastern zone of the cave where a general, slow water flow occurs. A strong increase of corrosion is due to turbulence, but an intense corrosion maintains however in the whole water body, also where the water movement is slow, as verified in the two pools tested by Galdenzi et al. (1997).

Corrosion is less intense in Lago Verde, where sulfidic, unstratified stagnant water is directly in contact with the atmosphere and exposed to direct recharge of seepage water.

Interesting results were also found in the stratified ground-water of Lago delle Anguille (Fig. 2) by Mariani et al. (2007), where sulfidic water stays 4.5 $\mathrm{m}$ below the water-table, overlain by a surface layer of bicarbonate water, $1.5 \mathrm{~m}$ thick, and an intermediate layer of weakly mineralized and $\mathrm{O}_{2}$-rich water. The maximum weight loss occurred in the upper part of the sulfidic layer, near the interface between the reducing and oxidizing environment (average value $\sim 0.09 \% \mathrm{a}^{-1}$, corresponding to $\sim 1.7 \mathrm{~mm} \mathrm{ka}^{-1}$ ). The values decreased in the deep part of the sulfidic layer (average value $\sim 0.07 \% \mathrm{a}^{-1}$, corresponding to $\sim 1.3 \mathrm{~mm}$ $\mathrm{ka}^{-1}$ ), and were very low in the intermediate weakly mineralized layer. The easier availability of oxygen near the chemocline was considered the probable cause of the increase in corrosion.

Subsequent researches (Hagemann, 2007) showed that the biofilms coming from these tablets contain mainly Deltaproteobacteria, which are often reported as sulfate and sulfur reducers (Hegemann, 2007). The author supposed that these bacteria might contribute to sulfur cycling, favoring biotic and abiotic oxidation near the chemocline, where $\mathrm{O}_{2}$ is available.

The values of weight loss in the Mariani et al. experiment are very low, in part due to the characteristics of the tablets. In fact, using the same Carrara marble tablets, similar rates were also obtained in Lago Verde (Macalady, personal communication). Therefore, the maximum corrosion rate of Lago delle Anguille can be considered closer to those measured in Lago Verde than in Ramo Sulfureo.

All the available data show that the corrosion rates measured in the cave increase depending mainly by the recharge of $\mathrm{O}_{2}$ for $\mathrm{H}_{2} \mathrm{~S}$ oxidation, from the atmosphere or vadose water. In the stagnant pools, with less diluted water coming from deep zones of the aquifer, as in Lago Verde, dissolution is lower than in diluted flowing water of Ramo Sulfureo. Similarly, in the lowest part of the Lago delle Anguille the rate decreases.
The availability of oxygen is influenced by many factors: the existence of large surface areas of sulfidic water exposed to the cave atmosphere; the flow of water and its turbulence; the direct, fast recharge of $\mathrm{O}_{2}-$ rich meteoric water from the karst surface; and the slow recharge of seepage water from the vadose zone. In Ramo Sulfureo all the favorable conditions exist simultaneously: recharge of freshwater, active water flow, and exposure to the cave atmosphere. It explains the high rate measured in the whole water body, even where the water flow is slow.

\section{MORPHOGENETIC IMPLICATIONS}

The Frasassi caves are a network of mainly horizontal passages and rooms, organized in several superimposed levels, the genesis of which is related to steps in the deepening of the river valley and related base level. The lower parts of the cave system are developed near the present local base level, at $200 \mathrm{~m}$ of altitude, and include two main levels, at 225 and $250 \mathrm{~m}$, and some minor. These caves formed in the Middle and Upper Pleistocene, as confirmed by correlation with the gravel deposits in the river valleys (Bocchini \& Coltorti 1990) and by Uranium series dating (Taddeucci et al., 1992). Some further caves (Buco Cattivo and Mezzogiorno-Frasassi cave systems) are known at a higher altitude, between 360 and $500 \mathrm{~m}$, which developed before the end of Early Pleistocene, when tectonic uplift and climatic changes caused the deepening of the valleys (Ambrosetti et al., 1982).

The lower levels developed under geomorphologic and hydrogeologic conditions similar to the current ones, and for this reason cave-forming processes that

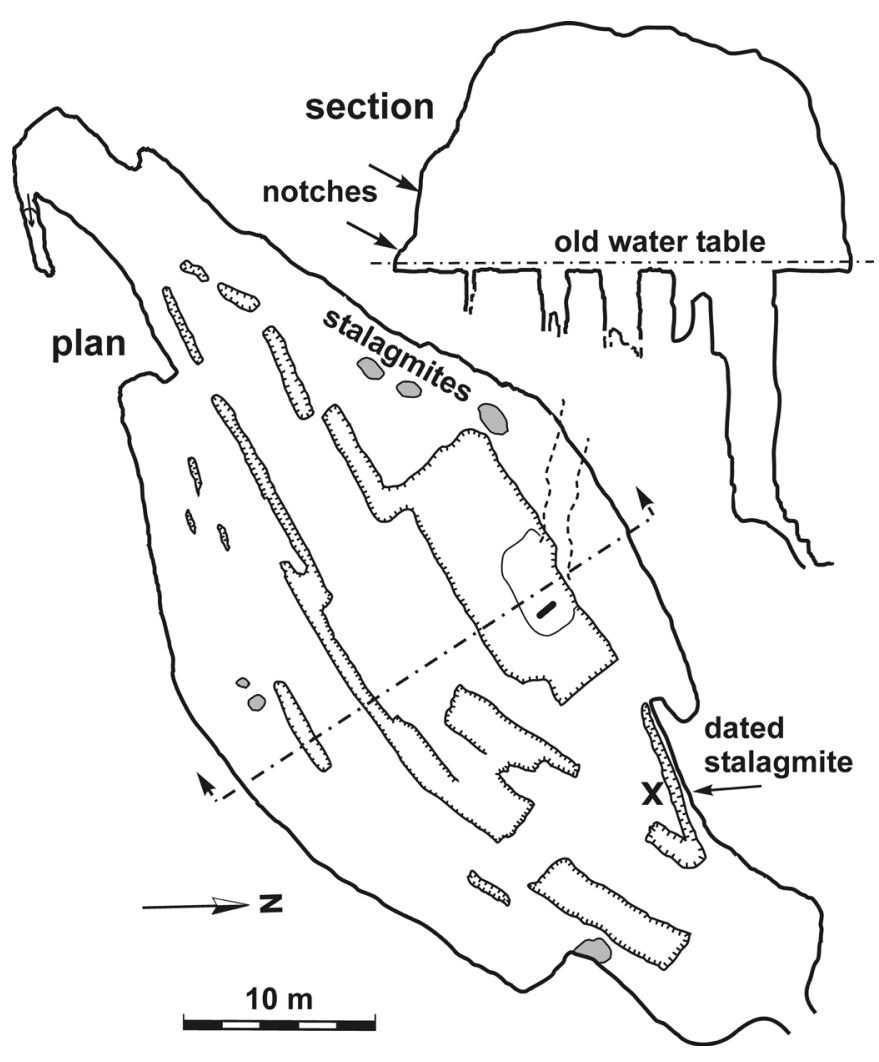

Fig. 10. Sala del Limone (Grotta Grande del Vento). Plan view and section. 
are active in the lowest zones can be compared with the morphologies and deposits of the inactive zones (Galdenzi, 1990; Galdenzi \& Maruoka, 2003).

Some vertical and inclined passages were produced by the ascending flow of sulfidic water, but in general the solutional processes prevailed in the shallow phreatic zone. Many rooms and passages were enlarged above the water table due to acidic condensation water from the oxidation of $\mathrm{H}_{2} \mathrm{~S}$ and also from the high content of $\mathrm{CO}_{2}$. Wide interfaces between groundwater and cave atmosphere existed when the watertable level remained stable for a long time, favoring $\mathrm{H}_{2} \mathrm{~S}$ oxidation and cave enlargement, as testified by large deposits of gypsum (Galdenzi, 1990).

The development of each cave level is influenced by two main factors: the length of time the water table remains at the same altitude, that is directly influenced by the general geomorphic evolution of the area; the intensity of corrosion, that varies both in the different zones of the cave and with time. The linear corrosion rate measured in the cave can be used to verify if the cave morphology is compatible with the active processes, also considering the presumable lifetime of each level. In the following paragraphs, the characteristics of two typical cave rooms will be described in detail.

\section{Sala del Limone}

This room has a name that derives from its shape, similar to a lemon cut in half lengthwise; it is about $25 \mathrm{~m}$ wide and $60 \mathrm{~m}$ long, and the maximum height is almost $15 \mathrm{~m}$ (Fig. 10). The ceiling resembles a cupola, while the floor forms a flat surface of limestone, without significant sediments, cut along its length by many deep feeder fissures, that represent the source of the sulfidic water (Fig. 11). The room can be entered through one of these crevasses or by a small passage at the downstream termination, that in the past was the outlet of the water. During solution of the room, a wide lake with slowly moving water was present, and a large amount of corrosion due to condensation water occurred above the water-table.

The room is in the major cave level at $250 \mathrm{~m}, 50$ $\mathrm{m}$ above the water-table. The level is formed by many large rooms, that reach dimensions similar or slightly wider than those of Sala del Limone. A further, lessdeveloped upper level is at $\sim 265 \mathrm{~m}$. The oldest stalagmite dated in the cave, $200 \mathrm{ka}$ old is in Sala del Limone (Taddeucci et al., 1992). After the deposition of this dripstone began, there is no evidence for sulfuric acid corrosion and the evolution due to sulfidic water circulation can be considered finished.

Applying to this room the linear corrosion rate measured in the active zones of the cave, we can roughly verify that the dissolution of $\sim 10 \mathrm{~m}$ of limestone on each cave wall at the water table level required $\sim 150 \mathrm{ka}$ using values similar to those measured in Ramo Sulfureo ( 70 $\left.\mathrm{mm} \mathrm{ka}^{-1}\right)$, over 400 ka with those measured in Lago Verde $\left(\sim 24 \mathrm{~mm} \mathrm{ka}^{-1}\right)$. Only the first time interval (150 ka) is compatible with the cave history, assuming that this karst level and the upper minor one should have formed during the lower part of Middle Pleistocene, after that the river downcutting produced the deepening of the valley floor and before flowstone deposition began in the room, $200 \mathrm{ka}$ ago.

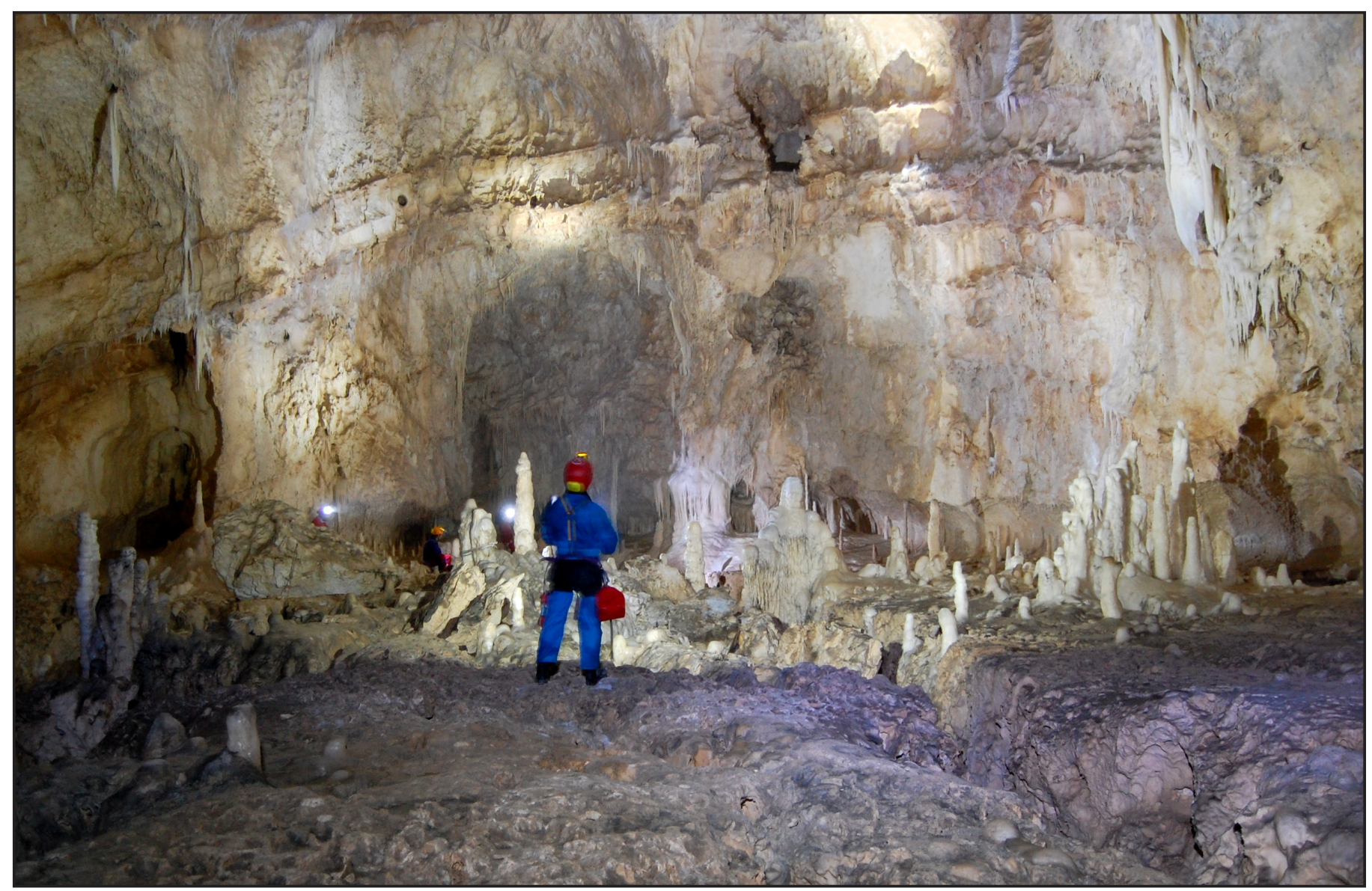

Fig. 11. Sala del Limone (Grotta Grande del Vento): the flat floor cut by crevasses. 


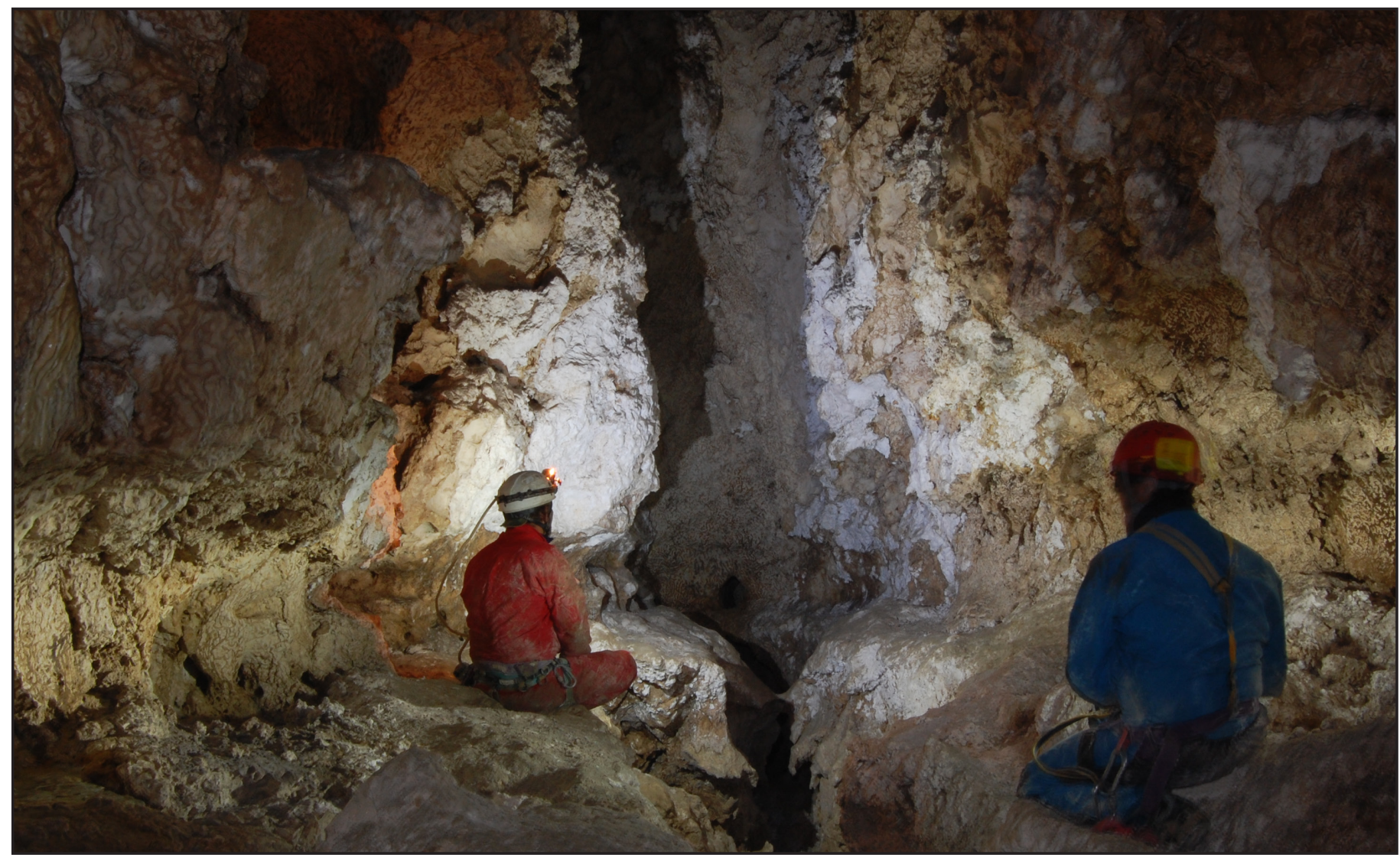

Fig. 12. The characteristic section of the passage after Pozzo dei Cristalli (Grotta del Fiume). The notches and the replacement gypsum in the walls formed when the passage was partly flooded by sulfidic water.

\section{Pozzo dei Cristalli}

Below the Pozzo dei Cristalli, a horizontal passage formed $3.5 \mathrm{~m}$ above the present ground-water level acquiring a characteristic cross section (Fig. 12). The passage shape resulted from the widening of a pre-exixting karstified fracture, due to a weak flow of sulfidic water coming from a feeder located upstream. Replacement gypsum formed in the whole passage and reached high intensity in the feeder zone. A network of wide passages at a few meters above the water level is know only in the northeastern part of the Grotta del Fiume (Bocchini $\&$ Coltorti, 1990) and is considered to be very recent. Speleothems dated with U series in this zone had ages less than $10 \mathrm{ka}$ (Taddeucci et al., 1992). Furthermore, in a different internal part of the cave Mariani et al. (2007) documented using ${ }^{14} \mathrm{C}$ dating that the water-table progressively fell $4.5 \mathrm{~m}$ in the last $8 \mathrm{ka}$. These data and the well preserved wall features confirm that the final shape of the passage was reached in a short period of time, probably during the Holocene.

Also in this case, we can try to verify if the present linear corrosion rate is compatible with the observed morphologies. The gypsum that covers the walls does not exceed $10 \mathrm{~cm}$ of thickness, corresponding to the replacement of $\sim 4 \mathrm{~cm}$ of limestone, considered $240 \%$ volume increase, as verified in Monte Cucco Caves (Galdenzi, 2004). Using the average corrosion rate ( 70 $\left.\mathrm{mm} \mathrm{ka}^{-1}\right)$ measured in the cave atmosphere by Galdenzi et al. (1997) less then 1000 years are sufficient to produce the observed gypsum crust. In the same time, with the maximum linear corrosion rate $\left(1 \mathrm{~mm} \mathrm{a}^{-1}\right)$ over $1 \mathrm{~m}$ of corrosion could be due to slow, weakly turbulent water flow.

As evidenced by these data, the notches at the old water level and the wall enlargement due to gas exhalations could occur in a short time.

\section{CONCLUSIONS}

The corrosion rate due to the sulfidic groundwater corrosion of limestone tablets showed that significant variations not only occur in the cave atmosphere due to the condensation water, as already shown by Galdenzi et al. (1997), but also in the shallow phreatic zone.

The highest rates $\left(68-119 \mathrm{~mm} \mathrm{ka}^{-1}\right)$ were found in the Ramo Sulfureo, in a zone of the sulfidic aquifer where the flow is relatively fast, while in the stagnant water of Lago Verde the average values remained lower $\left(\sim 24 \mathrm{~mm} \mathrm{ka}^{-1}\right)$. The increase of water aggressiveness in the Ramo Sulfureo can be related to the hydraulic conditions facilitating the recharge of oxygen to the sulfidic water.

Significant differences in the corrosion rate measured in each water body are also due to local factors, as the turbulence of the water or the distance from the oxidation surface. Bacteria biofilms, that play an important role in the sulfide oxidation, seem to represent a physical barrier that reduces the dissolving power of the water on the limestone.

The size of the main rooms and passages is compatible with the corrosion rate measured in the Ramo Sulfureo, while the values from Lago Verde are 
too low to create voids as large as those forming the main cave levels. The development of two important and some minor cave levels, in fact, should have occurred wholly after the end of lower Pleistocene, in a period that should not exceed $700 \mathrm{ka}$.

Assuming the average corrosion rate measured in the Ramo Sulfureo, the large rooms of the main cave level at an altitude of $250 \mathrm{~m}$ could form at the old water-table surface in $\sim 150 \mathrm{ka}$. The highest measured values can also justify the shape that some passages acquired in a short time, probably during Holocene.

The possibility that the corrosion rates vary in different zones of the cave can explain why some levels are limited in extent. The lowest level, for example, is present at $\sim 2-4 \mathrm{~m}$ above the water table only in the spring area, where active water flow exists today, while it is not well-developed in the remaining part of the cave, probably as a consequence of a low corrosion intensity due to water stratification.

The development of the most important cave levels cannot be simply related to the stages of valley deepening. The water table must also remain stable for a long period, and the hydraulic conditions must be present to promote a high corrosion rate. The amount of sulfidic water rising from depth and freshwater descending from the surface, the possibility of widespread gas exchanges with the cave atmosphere, and flow conditions in the aquifer, can therefore influence the shape and size of each cave level.

\section{ACKNOWLEDGMENTS}

I wish to thank Margaret and Arthur Palmer for their suggestions that helped to complete and adapt the text. The costs for water monitoring and tablets preparation were supported by a grant from the Marche Region for the project "The sulfidic spring of Frasassi: study of seasonal changes related to speleogenetic evolution in the area" of Gruppo Grotte Recanati, G.S. CAI Macerata, C.R.S. "Nottoloni" Macerata, G.A.SP. Civitanova Marche, G.S. Al.Va.P. Pioraco. Special thanks to Alfredo Campagnoli ${ }^{\dagger}$ together with the speleologists of the same cave groups, to Fabio Baldoni and my sons Andrea and Gabriele for their help in the field work.

\section{REFERENCES}

Ambrosetti P., Carraro F., Deiana G. \& Dramis F., 1982 - Il sollevamento dell'Italia Centrale tra il Pleistocene inferiore e il Pleistocene medio. C.N.R., Progetto Finalizzato "Geodinamica”, Pubbl. 513, II: 219-223.

Bocchini A. \& Coltorti M., 1990 - Il complesso carsico Grotta del Fiume Grotta Grande del Vento e l'evoluzione geomorfologica della Gola di Frasassi. In: Galdenzi S. \& Menichetti M. (Eds)., Il carsismo della Gola di Frasassi. Memorie Istituto Italiano Speleologia, s. II, 4: 155-180.

Davis D.G., 1980 - Cave development in the Guadalupe Mountains: a critical review of recent hypotheses. National Speleological Society Bulletin, 42 (3): 42-48.

Egemeier S.J., 1981 - Cavern development by thermal waters. National Speleological Society Bulletin, 43: 31-51.
Engel A.S., Stern L.A. \& Bennet P.C., 2004 - Microbial contributions to cave formation: new insights into sulfuric acid speleogenesis. Geology, 32: 369-372. http://dx.doi.org/10.1130/G20288.1

Galdenzi S., 1990 - Un modello genetico per la Grotta Grande del Vento. In: Galdenzi S. \& Menichetti M. (Eds), Il carsismo della Gola di Frasassi. Memorie Istituto Italiano di Speleologia, s. II, 4: 123-142.

Galdenzi S., 2004 - I depositi di gesso nella Grotta di Faggeto Tondo: nuovi dati sull'evoluzione geomorfologia dell'area di Monte Cucco (Italia centrale). Studi Geologici Camerti, nuova serie, 2: 71-83.

Galdenzi S., Cocchioni M., Morichetti L., Amici V. \& Scuri S., 2008 - Sulfidic ground-water chemistry in the Frasassi Caves, Italy. Journal of Cave and Karst Studies, 70: 94-107.

Galdenzi S. \& Maruoka T., 2003 - Gypsum deposits in the Frasassi Caves, central Italy. Journal of Cave and Karst Studies, 65: 11125-1365.

Galdenzi S., Menichetti M. \& Forti P., 1997 - La corrosione di placchette calcaree ad opera di acque sulfuree: dati sperimentali in ambiente ipogeo. Proceedings $12^{\text {th }}$ International Congress of Speleology, Le Chaux-de-Fonds, Switzerland, 1: 187190.

Galdenzi S., Menichetti M., Sarbu S. \& Rossi A., 1999 - Frasassi caves: a biogenic hypogean karst system? Proceedings European Conference Karst 99, Grands Causses, Vercors, France, Cagep: Université de Provence, Etudes de Géographie physique, travaux 1999, suppl. 28: 101-106.

Gams I., 1985 - International comparative measurement of surface solution by means of standard limestone tablets. Razprave iv. Razreda, 26: 361-386.

Hegemann R.F., 2007 - Microbial influence on carbonate dissolution in stratified waters in the Frasassi Cave System, Italy. Senior Thesis, Department of Geosciences, Pennsylvania State University (USA): 38 p.

Hill C.A., 1987 - Geology of Carlsbad Caverns and other caves of the Guadalupe Mountains. New Mexico and Texas, New Mexico Bureau of Mines and Mineral Resources Bulletin, 117: 150 p.

Hose L.D., Palmer A.N., Palmer M.V., Northup D.E., Boston P.J. \& DuChene H.R., 2000 - Microbiology and geochemistry in a hydrogen-sulfide-rich karst environment. Chemical Geology, 169: 399-423. http://dx.doi.org/10.1016/S0009-2541(00)00217-5

Jones D.S., Polerecky L., Dempsey B.A., Galdenzi S. \& Macalady J.L., 2011 - Biological and abiotic controls on sulfide oxidation, acid production, and carbonate dissolution in the Frasassi Cave System, Italy. Geological Society of America Abstracts with Programs, 43: 328.

Macalady J.L., Jones D.S. \& Lyon E.H., 2007 - Extremely acidic, pendulous microbial biofilms from the Frasassi cave system, Italy. Environmental Microbiology, 9: 1402-1414. http://dx.doi.org/10.1111/j.1462-2920.2007.01256.x

Macalady J.L., Lyon E.H., Koffman B., Albertson L.K., Meyer K., Galdenzi S. \& Mariani S., 2006 - Dominant microbial populations in limestone-corroding stream biofilms, Frasassi cave system, Italy. Applied and Environmental Microbiology, 72: 55965609. http://dx.doi.org/10.1128/AEM.00715-06 
Mariani S., Mainiero M., Barchi M., van der Borg K., Vonhof H. \& Montanari A., 2007 - Use of speleologic data to evaluate Holocene uplifting and tilting: an example from the Frasassi anticline (northeastern Apennines, Italy). Earth and Planetary Science Letters, 257: 313-328. http://dx.doi.org/10.1016/j.eps1.2007.02.045

Klimchouk and Ford (Eds)., 2009 - Hypogene speleogenesis and karst hydrogeology of artesian basins. Ukrainian Institute of Speleology and Karstology. Special Paper 1: 296 p.

Palmer A.M., 1991 - Origin and morphology of limestone caves. Geological Society American Bulletin, 103: 1-21. http://dx.doi.org/10.1130/00167606(1991)103<0001:OAMOLC >2.3.CO;2

Principi P., 1931 - Fenomeni di idrologia sotterranea nei dintorni di Triponzo (Umbria). Le Grotte d'Italia, 5:1-4.
Sarbu S.M., Galdenzi S., Menichetti M. \& Gentile G., 2000 - Geology and Biology of the Frasassi Caves in Central Italy, an ecological multi-disciplinary study of a hypogenic underground ecosystem. In: Wilkens H. et al. (Eds)., Ecosystems of the world. New York: Elsevier: 359-378.

Sarbu S.M. \& Kane T.C., 1995 - A subterranean chemoautotrophically based ecosystem. National Speleological Society Bulletin, 57: 91-98.

Taddeucci A., Tuccimei P. \& Voltaggio M., 1992 - Studio geocronologico del complesso carsico "Grotta del Fiume - Grotta Grande del Vento" (Gola di Frasassi, AN) e indicazioni paleoambientali. Il Quaternario, 5: 213222.

Trudgill S.T., 1975 - Measurement of erosional weight loss of rock tablets. British Geomorphological Research Group. Technical Bulletin, 17: 13-19.

Appendix 1. Weight loss and corrosion rate for the limestone tablets.

\section{Grotta del Fiume - Ramo Sulfureo}

\begin{tabular}{|c|c|c|c|c|c|}
\hline tablet & Location & $\begin{array}{c}\text { Exposure length } \\
\text { (days) }\end{array}$ & $\begin{array}{l}\text { Weight loss } \\
\text { (g) }\end{array}$ & $\begin{array}{l}\text { Weight loss } \\
\left(\mathrm{mg} \mathrm{cm}^{-2} \mathrm{a}^{-1}\right)\end{array}$ & $\begin{array}{l}\text { Corrosion rate } \\
\left(\mathrm{mm} \mathrm{ka}^{-1}\right)\end{array}$ \\
\hline A7 & Fixed, annual & 732 & 2.614 & 15.9 & 67.8 \\
\hline \multirow{3}{*}{ A14 } & \multirow{3}{*}{ Fixed, wet season } & $1^{\text {st }}$ period: 161 & 0.640 & 17.6 & 74.8 \\
\hline & & $2^{\text {nd }}$ period: 170 & 0.689 & 17.9 & 76.2 \\
\hline & & Total: $\quad 331$ & 1.329 & 17.7 & 75.5 \\
\hline \multirow{3}{*}{ A9 } & \multirow{3}{*}{ Fixed, wet season } & $1^{\text {st }}$ period: 161 & 0.671 & 18.1 & 77.5 \\
\hline & & $2^{\text {nd }}$ period: 170 & 0.781 & 19.9 & 85.4 \\
\hline & & Total: $\quad 331$ & 1.452 & 19.0 & 81.6 \\
\hline \multirow{3}{*}{ A6 } & \multirow{3}{*}{ Fixed, dry season } & $1^{\text {st }}$ period: 203 & 0.937 & 20.3 & 84.7 \\
\hline & & $2^{\text {nd }}$ period: 198 & 0.932 & 20.8 & 86.4 \\
\hline & & Total: $\quad 401$ & 1.869 & 20.5 & 85.5 \\
\hline \multirow{3}{*}{ A3 } & \multirow{3}{*}{ Fixed, dry season } & $1^{\text {st }}$ period: 203 & 1.013 & 22.1 & 92.5 \\
\hline & & $2^{\text {nd }}$ period: 198 & 0.928 & 20.8 & 86.9 \\
\hline & & Total: $\quad 401$ & 1.941 & 21.5 & 89.7 \\
\hline A8 & Floating, dry season & 203 & 10.562 & $230.3^{(1)}$ & $962.1^{(1)}$ \\
\hline A4 & Floating, dry season & 203 & 5.120 & $110.6^{(1)}$ & $472.1^{(1)}$ \\
\hline A12 & Floating, wet season & $161^{(2)}$ & & & \\
\hline A13 & Floating, wet season & $161^{(2)}$ & & & \\
\hline A15 & Floating, wet season & 163 & 1.041 & 28.2 & 119.3 \\
\hline A17 & Floating, wet season & 163 & 0.823 & 21.9 & 92.4 \\
\hline A24 & Floating, dry season & 208 & 1.260 & 27.1 & 115.6 \\
\hline A23 & Floating, dry season & 208 & 1.108 & 23.2 & 97.7 \\
\hline
\end{tabular}

\section{Grotta del Fiume - Lago Verde}

\begin{tabular}{|c|c|c|c|c|c|}
\hline B20 & Fixed, annual $(-0,20 \mathrm{~m})$ & 770 & 0.813 & 4.9 & 18.5 \\
\hline B22 & Fixed, annual $(-1,70 \mathrm{~m})$ & 770 & 0.879 & 5.5 & 21.5 \\
\hline \multirow{3}{*}{ A10 } & \multirow{3}{*}{ Floating, wet season } & $1^{\text {st }}$ period: 161 & 0.318 & 8.6 & 37.3 \\
\hline & & $2^{\text {nd }}$ period: 173 & 0.266 & 6.7 & 29.0 \\
\hline & & Total: $\quad 334$ & 0.584 & 7.6 & 33.0 \\
\hline \multirow{3}{*}{ A11 } & \multirow{3}{*}{ Floating, wet season } & $1^{\text {st }}$ period: 161 & 0.370 & 10.2 & 44.4 \\
\hline & & $2^{\text {nd }}$ period: 173 & 0.246 & 6.3 & 27.4 \\
\hline & & Total: $\quad 334$ & 0.616 & 8.2 & 35.6 \\
\hline A5 & Floating, dry season & $1^{\text {st }}$ period: 198 & 0.138 & 3.2 & 13.2 \\
\hline B28 & Floating, dry season & $2^{\text {nd }}$ period: $198^{(2)}$ & & & \\
\hline A25 & Floating, dry season & $1^{\text {st }}$ period: 208 & 0.323 & 6.7 & 28.7 \\
\hline B26 & Floating, dry season & $2^{\text {nd }}$ period: 208 & 0.299 & 6.4 & 24.5 \\
\hline
\end{tabular}

(1) Tablet not uniformly corroded in weakly turbulent water.

(2) Tablet lost in the ground-water. 